\title{
Expression of Lamin A/C in early-stage breast cancer and its prognostic value
}

\author{
IM Alhudiri1,3, CC Nolan², IO Ellis², A ELzagheid ${ }^{3}$, EA Rakha², \\ AR Green ${ }^{2}$, CJ Chapman ${ }^{1}$ \\ Divisions of Breast Surgery ${ }^{1}$ and Nottingham Breast Cancer Research, Division of Cancer and Stem Cells, \\ School of Medicine ${ }^{2}$, The University of Nottingham, Nottingham, UK. \\ Genetic Engineering department ${ }^{3}$, Biotechnology Research Centre, Tripoli, Libya \\ Correspondence to: Dr. Andrew Green, Division of Cancer and Stem Cells, School of Medicine, University \\ of Nottingham, Nottingham City Hospital, Nottingham, NG5 1PB; andrew.green@nottingham.ac.uk, +44 \\ (0) 1158231407
}




\begin{abstract}
Purpose: Lamins A/C, a major component of the nuclear lamina, plays key roles in maintaining nuclear integrity, regulation of gene expression, cell proliferation and apoptosis. Reduced lamin A/C expression in cancer has been reported to be a sign of poor prognosis. However, its clinical significance in breast cancer remains to be defined. This study aimed to evaluate expression and prognostic significance of lamin $\mathrm{A} / \mathrm{C}$ in early-stage breast cancer.
\end{abstract}

Methods: Using immunohistochemical staining of tissue microarrays, expression of lamin $\mathrm{A} / \mathrm{C}$ was evaluated in a large well-characterised series of early-stage operable breast cancer $(n=938)$ obtained from Nottingham Primary Breast Carcinoma Series. Association of lamin $\mathrm{A} / \mathrm{C}$ expression with clinicopathological parameters and outcome was evaluated.

Results: Positive expression rate of lamin A/C in breast cancer was $42.2 \%(\mathrm{n}=398)$. Reduced/loss of expression of lamin $\mathrm{A} / \mathrm{C}$ was significantly associated with high histological grade $(\mathrm{p}<0.001)$, larger tumour size $(\mathrm{p}=0.004)$, poor Nottingham Prognostic Index (NPI) score $(\mathrm{p}<0.001)$, lymphovascular invasion $(\mathrm{p}=0.014)$ and development of distant metastasis $(\mathrm{p}=0.027)$. Survival analysis showed that reduced/loss of expression of lamin $\mathrm{A} / \mathrm{C}$ was significantly associated with shorter breast cancer specific survival $(\mathrm{p}=0.008)$.

Conclusion: This study suggests lamin A/C plays a role in breast cancer and loss of its expression is associated with variables of poor prognosis and shorter outcome.

Keywords: Breast cancer, Lamin A/C, immunohistochemistry, tissue microarray, prognosis. 


\section{INTRODUCTION}

Lamins, type $\mathrm{V}$ intermediate filament proteins, are the major component of the nuclear lamina [1] and are classified into A (lamin A and C) and B types. Lamin A/C are implicated in a multitude of functions within the cell [2] including binding to chromatin, maintaining nuclear integrity, apoptosis and regulating gene expression and cell proliferation. Lamin proteins are involved in regulating cell proliferation through different mechanisms including oxidative stress and reactive oxygen species signalling pathways and modulation of phosphoinositide 3-kinase signaling pathway [3, 4]. A-type lamins also participate in many other cell functions through binding to a myriad of nuclear, signal transduction and gene regulatory proteins $[5,6]$.

Lamins are synthesized throughout the cell cycle and the lamina is depolymerized and repolymerized during mitotic prophase and telophase respectively $[7,8]$. Cells deficient in LMNA gene exhibit enhanced proliferation, impaired cellular migration and nuclear orientation $[9,10]$. Conversely, in vivo lamin $\mathrm{A} / \mathrm{C}$ over-expression inhibits cell proliferation [11]. Mutations in the LMNA gene cause different degenerative disorders collectively called laminopathies which are associated with a wide range of heritable diseases including muscular dystrophies and premature ageing [12].

Nuclear changes are hallmarks of cancer and diagnosis of malignant transformation in pathological specimens depends on the presence of characteristic alterations in nuclear shape and heterochromatin and also used in evaluation of grade and hence prognosis in breast cancer $[13,14]$. As lamins are thought to be a principal determinant of nuclear shape and architecture, it is hypothesised that they are responsible for the structural changes observed in cancer cells. Moreover, $\alpha$-helical rod domain of A-type lamins bind 
to chromatin both directly and indirectly through other proteins e.g. Emerin and laminassociated protein 2 (LAP2) [15-17].

Mechanisms underlying the role of lamin in cancer have been speculated and this has led to the conclusion that A-type lamins contribute to tumorigenesis and progression. A-type lamin in fibroblasts have important interactions with nuclear proteins, emerin and LAP $2 \alpha$, influencing the activity of oncogene $\beta$-catenin and Retinoblastoma protein $(\mathrm{pRb})$ growth regulators [18].

A-type Lamins are not only expressed in terminally differentiated mammalian cells; but are also found in embryonic stem cells but at low amounts [19, 20]. Lamins are differentially expressed in normal and cancer tissues. For instance both lamin A and C are highly expressed in basal and squamous cell carcinoma but lamin $\mathrm{C}$ is expressed in all layers of the normal epidermis while lamin A expression was absent in the normal basal layers [21]. In contrast, decreased expression of lamin $\mathrm{A} / \mathrm{C}$ is seen in small cell lung cancer (SCLC) but not in non-SCLC in which it was also aberrantly localised to the cytoplasm [22, 23]. Moreover, reduced expression of lamin A/C has also been reported in adenocarcinoma of stomach, colon, and oesophageal carcinoma [24]. Reduced or negative lamin $\mathrm{A} / \mathrm{C}$ expression is associated with poor prognosis in a number of cancers including gastric carcinoma, lymphomas, lung, colon and breast cancer [23, 25-29].

Some studies of lamin $\mathrm{A} / \mathrm{C}$ expression in breast cancer have also reported decreased expression [24, 28-31]. However, most of these studies included small sample sizes and with scarce comment of the clinical outcome.

To assess the prognostic effect of lamin $\mathrm{A} / \mathrm{C}$ in breast cancer and association with different clinical parameters, we investigated its expression in a large and well- 
characterised series of early-stage breast carcinoma with a long-term follow-up and correlated this with clinicopathological variables and outcome.

\section{MATERIALS AND METHODS}

\section{Patients and tissue specimens}

A total of 938 cases of operable invasive breast carcinoma obtained from Nottingham Tenovus Primary Breast Carcinoma Series were investigated. This is a well characterised series of primary breast carcinoma with long term follow-up that were routinely assessed for tumour type, tumour size, histological grade, vascular invasion and Nottingham Prognostic Index (NPI). The median follow up time was 146 months (range 1-244). Information on local and regional recurrence, presence of distance metastasis, lymph node status, survival and therapy were collected on a prospective basis. The patients were treated in a uniform way and the series has previously been used to study a wide range of biomarkers including oestrogen receptor (ER), progesterone receptor (PgR), HER2, EGFR, p53 and E-cadherin [32]. Breast cancer specific survival (BCSS) was defined as the length of time (in months) from the date of the primary surgery to the time of breast cancer-related death, and disease free interval (DFI) was defined as the length of time (in months) from the date of the primary surgery to the first locoregional recurrence or distant metastasis. NPI is derived as follows: NPI=0.2 x pathological tumour size $(\mathrm{cm})+$ histological grade (1-3) + lymph node stage. The NPI divides patients into three subgroups; good ( $\leq 3.4)$, moderate (3.41-5.4) and poor (>5.4) prognostic groups [33]. Patients were managed according to their hormonal status and NPI score; those with an NPI score $\leq 3.4$ received no adjuvant therapy, those with a NPI score $>3.4$ received 
Tamoxifen if ER positive ( \pm Zoladex if pre-menopausal) or classical cyclophosphamide, methotrexate and 5-fluorouracil if ER negative and fit enough to tolerate chemotherapy [34]. Patient details and clinicopathological characteristics are listed in Table 1.

Ethical approval for this study was granted by Nottingham Research Ethics committee 2 under the title of "Development of a molecular genetic classification of breast cancer"

\section{Immunohistochemistry}

Breast cancer tissue microarrays (TMA) were prepared as previously described [34]. The monoclonal antibody to lamin A/C (Cell signalling Mouse monoclonal antibody, \#2032) was used for immunohistochemical detection. After deparaffinisation in xylene and rehydration through graded alcohol, sections were immersed in $0.1 \mathrm{M}$ citrate buffer $\mathrm{pH}$ 6.0 and microwaved for 20 minutes in order to retrieve antigenicity. Once complete, slides were cooled and rinsed with Tris Buffered Saline (TBS) pH 7.6. Endogenous peroxidase activity was inhibited using peroxidase block (Dako Real peroxidise blocking solution, S2023) for 5 minutes followed by TBS rinse. Sections were incubated with Ultra $\mathrm{V}$ block (ThermoScientific TA-125-UB) to block non-specific staining by the primary antibody for 5 minutes at room temperature. The antibody was optimally diluted to 1:20 and incubated for 30 minutes at room temperature. After washing with TBS, all sections were incubated with a secondary antibody (dextran coupled peroxidase molecules and goat anti-mouse/rabbit immunoglobulin; Dako REAL ${ }^{\mathrm{TM}}$ EnVision $^{\mathrm{TM}} / \mathrm{HRP}$, Rabbit/Mouse bottle A, K5007) for $30 \mathrm{~min}$. Sections were washed in TBS and incubated with freshly prepared 3'3-diaminobenzidine (Dako Envision Kit, Bottle B and C, K5007) for 5 minutes and repeated once. After rinsing in TBS three times, sections were counterstained with haematoxylin (Dako Real Automation Haematoxylin, S3301) for 6 
min. After washing in tap water, the sections were dehydrated in ethanol, cleared in xylene and mounted with DPX (BDH, Poole, UK). A formalin-fixed paraffin embedded tissue section from a primary ductal carcinoma was used as a positive control for lamin A/C staining.

\section{Evaluation of immunohistochemical staining}

Immunoreactivity of Lamin A/C in the TMA cores was evaluated semi-quantitatively by assessing both percentage of cells stained and intensity of staining. Nuclear staining of the TMA cores was measured using the modified Histochemical-score (H-Score) with a range from 0 to 300 . H-score was calculated as the sum of the percentage of cells with weak, moderate and strong staining. The staining intensity was scored as 0 (no staining), 1 (weak staining), 2 (moderate staining), and 3 (strong staining). Only staining of the invasive malignant cells within the tissue cores was considered. TMAs were manually assessed using high resolution digital images (NanoZoomer; Hamamatsu Photonics, Welwyn Garden City, UK), at X20 magnification, using a web-based interface (Distiller; Slidepath Ltd, Dublin, Ireland). All samples were scored by one observer (IA) and each core was scored twice and the average taken. The intraobserver agreement was good as suggested by Cohen's kappa value $\varkappa=0.80$ and a $95 \%$ confidence interval between 0.93-0.68.

\section{Statistical Analysis}

Statistical analysis was performed using SPSS v18 statistical software. Chi-squared analyses were used for correlations between Lamin A/C expression and clinicopathological parameters, steroid receptors and biomarkers. Possible correlation between Lamin A/C expression levels and BCSS and disease free interval was examined 
using Kaplan-Meier curves and differences between the curves were analysed using the log-rank test. Cox regression models were used for multivariate analysis to test the effect of Lamin $\mathrm{A} / \mathrm{C}$ expression and clinicopathological parameters on disease-free survival and BCSS as well as its statistical independence. A P-value of $<0.05$ was considered statistically significant.

\section{RESULTS}

Immunohistochemical examination revealed positive staining of lamin $\mathrm{A} / \mathrm{C}$ localised to the nuclear envelope of invasive breast cancer cells (Figure 1). Stromal fibroblasts and vascular endothelial cells showed positive staining for nuclear lamin $\mathrm{A} / \mathrm{C}$ which provided a positive control for expression. A total of $96 \%$ (900/938) of cases demonstrated varying degrees of nuclear staining to lamin $\mathrm{A} / \mathrm{C}$ in the tumour cells while $4 \%$ (38/938) showed complete absence of nuclear staining. Data were categorised into two groups according to frequency distributions and Kaplan- Meier curves of the effect on BCSS and cut-off was selected using X-tile software [35]. Low/absent nuclear expression was defined as $\mathrm{H}$ score $\leq 150$ and high nuclear expression as $\mathrm{H}$-score $>150$. High expression of lamin A/C was observed in 398/938 (42.3\%) tumours while negative expression rate of lamin A/C was 540/938 (57.7\%).

\section{Correlation of lamin A/C expression with clinicopathological parameters}

Reduced/absent lamin $\mathrm{A} / \mathrm{C}$ expression was associated with high mitotic frequency and nuclear pleomorphism $(\mathrm{p}=<0.001)$, high grade tumours $(\mathrm{p}<0.001)$, larger tumours $(\mathrm{p}=0.004)$, vascular invasion $(\mathrm{p}=0.014)$, poor NPI score $(\mathrm{p}<0.001)$ and presence of distant metastases $(\mathrm{p}=0.027)($ Tables 2 and 3$)$. Negative expression of lamin $\mathrm{A} / \mathrm{C}$ was associated 
with invasive ductal/no special type and atypical medullary histological tumour types $(\mathrm{p}=0.002)$. Lamin $\mathrm{A} / \mathrm{C}$ expression was not associated with age at diagnosis, nodal stage, or loco-regional recurrence.

\section{Association of lamin A/C with biomarkers expression}

Relationships between lamin $\mathrm{A} / \mathrm{C}$ and biomarkers are summarised in Table 4. Tumours with high expression for lamin $\mathrm{A} / \mathrm{C}$ was significantly associated with $\mathrm{ER}(\mathrm{p}=0.002)$ and PgR positivity $(\mathrm{p}=0.001)$. On the other hand, HER 2 positive tumours had a negative association with lamin $\mathrm{A} / \mathrm{C}$ expression $(\mathrm{p}=0.005)$. Low lamin $\mathrm{A} / \mathrm{C}$ immunoreactivity was further correlated with triple negative status $(\mathrm{p}=0.026)$. Low Lamin $\mathrm{A} / \mathrm{C}$ expression also showed significant association with high $\mathrm{p} 53$ expression $(\mathrm{p}=0.001)$. There was no correlation between lamin A/C with either E-cadherin or Ki67 expression.

\section{Association of lamin A/C with patient outcome}

Tumours with reduced/absent Lamin A/C expression showed significantly shorter BCSS compared with those showing high expression for the biomarker $(\mathrm{p}=0.008)$ (Figure 2). On the other hand low/absent expression of lamin $\mathrm{A} / \mathrm{C}$ was associated with a trend for shorter DFI (distant metastasis $(\mathrm{p}=0.057)$ but there was no association with loco-regional recurrence $(\mathrm{p}=0.360)$ (Figures $3 \&$ \& $)$. High Lamin A/C expression was significantly associated with BCSS in ER positive ( $\mathrm{p}=0.026)$ but not ER negative patients $(\mathrm{p}=0.442)$. In multivariate analysis, expression of lamin $\mathrm{A} / \mathrm{C}$ was not independent of tumour grade, size and stage for both BCSS and DFI (Table 5). 


\section{DISCUSSION}

Lamins have been implicated in a variety of diseases and cancers and reported as having prognostic significance. In breast cancer, a study of lamin A/C expression on 56 invasive ductal carcinoma in tissue microarrays showed that lamin $\mathrm{A} / \mathrm{C}$ immunostaining was completely absent in 21/56 (38\%) of cases [30]. Our study showed that the majority of the breast cancer tissues demonstrated expression of lamin $\mathrm{A} / \mathrm{C}$; however, strong nuclear staining of invasive breast carcinoma cells was also evident in some cancer tissues.

In addition, we observed a correlation between high lamin $\mathrm{A} / \mathrm{C}$ expression and breast cancer clinico-pathological parameters associated with a good prognosis. Therefore breast tumours negative for lamin $\mathrm{A} / \mathrm{C}$ expression were more likely to have an aggressive phenotype. Many poorly differentiated tumours from various sites have been described to show reduced lamin A/C expression [24, 26, 28], which supports our findings whereas low lamin $\mathrm{A} / \mathrm{C}$ was associated with the poor prognostic NPI group, HER2 positive and triple negative tumours, vascular invasion, larger tumours and poor differentiation implying that measurement of lamin $\mathrm{A} / \mathrm{C}$ could provide an additional prognostic information.

However, multivariate analysis showed that lamin $\mathrm{A} / \mathrm{C}$ was not prognostically independent from tumour size, tumour grade and nodal stage. Two previous studies on lamin $\mathrm{A} / \mathrm{C}$ in breast cancer demonstrated that patients with tumour cells down-regulating Lamin $\mathrm{A} / \mathrm{C}$ had a poorer prognosis than those expressing the gene. However compared with our study, these studies had a much smaller sample size $(\mathrm{n}=115$ and $=73)$, shorter follow-up time and few clinicopathological criteria [28, 29]. 
Studies of lamin A/C in primary gastric carcinoma has also shown similar results to our findings, suggesting that tumour cells with low lamin $\mathrm{A} / \mathrm{C}$ expression had a poor prognosis and this was also an independent prognostic factor [26]. It has also been demonstrated that loss of lamin $\mathrm{A} / \mathrm{C}$ expression correlated with decreased overall survival in nodal diffuse large B-cell lymphoma [36].

Different mechanisms has been proposed for loss of lamin $\mathrm{A} / \mathrm{C}$ expression in cancer. LMNA gene silencing by $\mathrm{CpG}$ island promoter hypermethylation has led to inactivation of the gene and loss of lamin $\mathrm{A} / \mathrm{C}$ mRNA and protein expression in hematologic malignancies [36]. In normal cells, $\mathrm{CpG}$ islands are not subject to methylation at any stage of cell cycle and they permit the expression of that particular gene if the appropriate transcription factors are present and the chromatin is available to them. However, $\mathrm{CpG}$ islands of tumour suppressor genes, in tumour cells, become hypermethylated [37, 38]. Gene silencing caused by methylation is a common and early event in breast tumorigenesis [39-41]. Furthermore, methylation of the tumour suppressor genes in breast cancer is linked with poor prognostic indicators and hormonal receptor status [4246]. Lamin A/C might thus serve as a tumour suppressor based on these findings [47]. There are reports on hypermethylation of the regulatory regions of many breast tumourrelated genes such as p53, Cyclin D1, ER , PgR, E-cadherin, H-cadherin, Caspase-8, BRCA1, HOXA7, RASSF1 and HOXB13 further supporting the suggestion of lamin A/C hypermethylation $[39,48-50]$.

To determine whether lamin $\mathrm{A} / \mathrm{C}$ expression was correlated with cellular proliferation, we analysed co-expression of lamin A/C and Ki67 where the majority of highly proliferative tumours showed low expression for lamin $\mathrm{A} / \mathrm{C}$; however, the association was not 
statistically significant. In a study of basal cell carcinoma, reduced expression of lamin A was shown in most hyperproliferative tumours expressing Ki67. It seems that decreased A-type lamin expression is inversely proportional to proliferation in cancer cells.

Lamins are required for growth of the nuclear envelope and for increase of nuclear volume during the cell cycle and progression into $\mathrm{S}$ phase is dependent on the possession of a certain nuclear volume [51]. In addition, the down-regulation of lamins leads to abnormal condensation of chromatin. This may explain the high association of lamin A/C negative expression with high grade mitosis.

This study suggests lamin $\mathrm{A} / \mathrm{C}$ expression as a potential prognostic biomarker for early operable invasive breast cancer. Our findings indicate that lamin $\mathrm{A} / \mathrm{C}$ expressing tumours are associated with better breast cancer specific survival and reduced lamin A/C expression is associated with more aggressive tumours. Further analysis of lamin A and lamin $\mathrm{C}$ expression would be useful to investigate if there is differential expression and effect on clinical outcome comparing with normal breast samples. DNA methylation and gene silencing studies of LMNA gene is interesting to study the role of lamin $\mathrm{A} / \mathrm{C}$ in breast tumourigenesis.

\section{Acknowledgments}

We thank the Nottingham Health Science Biobank and Breast Cancer Now Tissue Bank for the provision of tissue samples. The authors gratefully acknowledge the support of the Libyan authority for research, science and technology.

\section{Compliance with Ethical Standards:}

Conflict of interest Authors declare that they have no conflict of interests 
Ethical approval All procedures performed in studies involving human participants were in accordance with the ethical standards of the institutional and/or national research committee and with the 1964 Helsinki declaration and its later amendments or comparable ethical standards. This study was approved by the Nottingham Research Ethics Committee 2 under the title "Development of a molecular genetic classification of breast cancer".

Informed consent Informed consent was obtained from all individual participants included in the study. 


\section{References:}

1. Lammerding J, Fong LG, Ji JY, et al. (2006) Lamins a and C but not lamin B1 regulate nuclear mechanics. J Biol Chem 281:25768-25780. doi: 10.1074/ jbc.M513511200

2. Butin-Israeli V, Adam SA, Goldman AE, Goldman RD (2012) Nuclear lamin functions and disease. Trends Genet 28:464-471. doi: 10.1016/j.tig.2012.06.001

3. Kong L, Schäfer G, Bu H, et al. (2012) Lamin A/C protein is overexpressed in tissue-invading prostate cancer and promotes prostate cancer cell growth, migration and invasion through the PI3K/AKT/PTEN pathway. Carcinogenesis 33:751-759. doi: 10.1093/carcin/bgs022

4. Eckersley-Maslin MA, Bergmann JH, Lazar Z, Spector DL (2013) Lamin A/C is expressed in pluripotent mouse embryonic stem cells. Nucleus 4:53-60. doi: $10.4161 /$ nucl.23384

5. Marmiroli S, Bertacchini J, Beretti F, et al. (2009) A-type lamins and signaling: the PI 3-kinase/Akt pathway moves forward. J Cell Physiol 220:553-561. doi: $10.1002 /$ jcp. 21807

6. Jung H, Lee J, Yang S, et al. (2013) Nuclear lamins in the brain-new insights into function and regulation. Mol Neurobiol 47:290-301. doi: 10.1007/ s12035-012-8350-1.Nuclear

7. Gerace L, Comeau C, Benson M (1984) Organization and modulation of nuclear lamina structure. J Cell Sci Suppl 1:137-160.

8. Ivorra C, Kubicek M, González JM, et al. (2006) A mechanism of AP-1 suppression through interaction of c-Fos with lamin A/C. Genes Dev 20:307-320. doi: 20/3/307 [pii]10.1101/gad.349506

9. Houben F, Willems CHMP, Declercq ILJ, et al. (2009) Disturbed nuclear orientation and cellular migration in A-type lamin deficient cells. Biochim Biophys Acta - Mol Cell Res 1793:312-324. doi: 10.1016/J.BBAMCR.2008.10.003

10. Ho CY, Jaalouk DE, Vartiainen MK, Lammerding J (2013) Lamin A/C and emerin regulate MKL1-SRF activity by modulating actin dynamics. Nature 497:507-513. doi: $10.1038 /$ nature12105

11. Lee KK, Haraguchi T, Lee RS, et al. (2001) Distinct functional domains in emerin bind lamin A and DNA-bridging protein BAF. J Cell Sci 114:4567-4573.

12. Worman HJ (2012) Nuclear lamins and laminopathies. J Pathol 226:316-325. doi: $10.1002 /$ path.2999 
13. Elston CW, Ellis IO (1991) Pathological prognostic factors in breast cancer. I. The value of histological grade in breast cancer: experience from a large study with long-term follow-up. Histopathology 19:403-10.

14. Zink D, Fische AH, Nickerson JA (2004) Nuclear structure in cancer cells. Nat Rev Cancer 4:677-687. doi: 10.1038/nrc1430

15. Solovei I, Wang AS, Thanisch K, et al. (2013) LBR and lamin A/C sequentially tether peripheral heterochromatin and inversely regulate differentiation. Cell 152:584-598. doi: 10.1016/j.cell.2013.01.009

16. Brachner A, Foisner R (2014) Lamina-associated polypeptide (LAP) $2 \alpha$ and other LEM proteins in cancer biology. Adv Exp Med Biol 773:143-163. doi: 10.1007/978-1-4899-8032-8_7

17. Qi Y-X, Yao Q-P, Huang K, et al. (2016) Nuclear envelope proteins modulate proliferation of vascular smooth muscle cells during cyclic stretch application. Proc Natl Acad Sci 113:5293-5298. doi: 10.1073/pnas.1604569113

18. Markiewicz E, Dechat T, Foisner R, et al. (2002) Lamin A/C binding protein LAP2alpha is required for nuclear anchorage of retinoblastoma protein. Mol Biol Cell 13:4401-4413. doi: 10.1091/mbc.E02-07-0450

19. Lin F, Worman HJ (1993) Structural organization of the human gene encoding nuclear lamin A and nuclear lamin C. J Biol Chem 268:16321-16326.

20. Eckersley-Maslin MA, Bergmann JH, Lazar Z, Spector DL (2013) Lamin A/C is expressed in pluripotent mouse embryonic stem cells. Nucleus 4:53-60. doi: 10.4161/nucl.23384

21. Tilli CM, Ramaekers FC, Broers JL, et al. (2003) Lamin expression in normal human skin, actinic keratosis, squamous cell carcinoma and basal cell carcinoma. Br J Dermatol 148:102-109. doi: 5026 [pii]

22. Broers JL, Raymond Y, Rot MK, et al. (1993) Nuclear A-type lamins are differentially expressed in human lung cancer subtypes. Am J Pathol 143:211-20.

23. Kaspi E, Frankel D, Guinde J, et al. (2017) Low lamin A expression in lung adenocarcinoma cells from pleural effusions is a pejorative factor associated with high number of metastatic sites and poor Performance status. PLoS One 12:e0183136. doi: 10.1371/journal.pone.0183136

24. Moss SF, Krivosheyev V, de Souza A, et al. (1999) Decreased and aberrant nuclear lamin expression in gastrointestinal tract neoplasms. Gut 45:723-729.

25. Prokocimer M, Margalit A, Gruenbaum Y (2006) The nuclear lamina and its proposed roles in tumorigenesis: projection on the hematologic malignancies and future targeted therapy. J Struct Biol 155:351-360. doi: S1047-8477(06)00105-5 [pii]10.1016/j.jsb.2006.02.016

26. Wu Z, Wu L, Weng D, et al. (2009) Reduced expression of lamin A/C correlates with poor histological differentiation and prognosis in primary gastric carcinoma. $\mathbf{J}$ Exp Clin Cancer Res 28:8. doi: 10.1186/1756-9966-28-8

27. Belt EJT, Fijneman RJA, van den Berg EG, et al. (2011) Loss of lamin A/C expression in stage II and III colon cancer is associated with disease recurrence. Eur J Cancer 47:1837-45. doi: 10.1016/j.ejca.2011.04.025

28. Wazir U, Ahmed M, Bridger J, et al. (2013) The clinicopathological significance of lamin A/C, lamin B1 and lamin B receptor mRNA expression in human breast cancer. Cell Mol Biol Lett 18:595-611. doi: 10.2478/s11658-013-0109-9 
29. Matsumoto A, Hieda M, Yokoyama Y, et al. (2015) Global loss of a nuclear lamina component, lamin A/C, and LINC complex components SUN1, SUN2, and nesprin-2 in breast cancer. Cancer Med 4:1547-1557. doi: 10.1002/cam4.495

30. Capo-chichi CD, Cai KQ, Smedberg J, et al. (2011) Loss of A-type lamin expression compromises nuclear envelope integrity in breast cancer. Chin J Cancer 30:415-25. doi: 1944-446X201106415 [pii]

31. Aljada A, Doria J, Saleh AM, et al. (2016) Altered Lamin A/C splice variant expression as a possible diagnostic marker in breast cancer. Cell Oncol 39:161174. doi: 10.1007/s13402-015-0265-1

32. Abd El-Rehim DM, Ball G, Pinder SE, et al. (2005) High-throughput protein expression analysis using tissue microarray technology of a large wellcharacterised series identifies biologically distinct classes of breast cancer confirming recent cDNA expression analyses. Int J Cancer 116:340-350. doi: 10.1002/ijc.21004

33. Kollias J, Murphy CA, Elston CW, et al. (1999) The prognosis of small primary breast cancers. Eur J Cancer 35:908-912. doi: S0959-8049(99)00056-8 [pii]

34. Madjd Z, Pinder SE, Paish C, et al. (2003) Loss of CD59 expression in breast tumours correlates with poor survival. J Pathol 200:633-639. doi: 10.1002/path. 1357

35. Camp RL, Dolled-Filhart M, Rimm DL (2004) X-tile: a new bio-informatics tool for biomarker assessment and outcome-based cut-point optimization. Clin Cancer Res 10:7252-7259.

36. Agrelo R, Setien F, Espada J, et al. (2005) Inactivation of the lamin A/C gene by $\mathrm{CpG}$ island promoter hypermethylation in hematologic malignancies, and its association with poor survival in nodal diffuse large B-cell lymphoma. J Clin Oncol 23:3940-7. doi: 10.1200/JCO.2005.11.650

37. Jones PA, Laird PW (1999) Cancer epigenetics comes of age. Nat Genet 21:163167. doi: 10.1038/5947

38. Baylin SB, Esteller M, Rountree MR, et al. (2001) Aberrant patterns of DNA methylation, chromatin formation and gene expression in cancer. Hum Mol Genet 10:687-92.

39. Widschwendter M, Jones PA (2002) DNA methylation and breast carcinogenesis. Oncogene 21:5462-5482. doi: 10.1038/sj.onc.1205606

40. Yan PS, Venkataramu C, Ibrahim A, et al. (2006) Mapping geographic zones of cancer risk with epigenetic biomarkers in normal breast tissue. Clin Cancer Res 12:6626-6636. doi: 12/22/6626 [pii]10.1158/1078-0432.CCR-06-0467

41. Cheng ASL, Culhane AC, Chan MWY, et al. (2008) Epithelial progeny of estrogen-exposed breast progenitor cells display a cancer-like methylome. Cancer Res 68:1786-96. doi: 10.1158/0008-5472.CAN-07-5547

42. Sunami E, Shinozaki M, Sim MS, et al. (2008) Estrogen receptor and HER2/neu status affect epigenetic differences of tumor-related genes in primary breast tumors. Breast Cancer Res 10:R46. doi: bcr2098 [pii]10.1186/bcr2098

43. Jing F, Yuping W, Yong C, et al. (2010) CpG island methylator phenotype of multigene in serum of sporadic breast carcinoma. Tumour Biol 31:321-331. doi: 10.1007/s13277-010-0040-X

44. Karray-Chouayekh S, Trifa F, Khabir A, et al. (2010) Aberrant methylation of 
RASSF1A is associated with poor survival in Tunisian breast cancer patients. $\mathrm{J}$ Cancer Res Clin Oncol 136:203-210. doi: 10.1007/s00432-009-0649-6

45. Sharma G, Mirza S, Parshad R, et al. (2010) Clinical significance of promoter hypermethylation of DNA repair genes in tumor and serum DNA in invasive ductal breast carcinoma patients. Life Sci 87:83-91. doi: S0024-3205(10)00198-0 [pii]10.1016/j.lfs.2010.05.001

46. Swift-Scanlan T, Vang R, Blackford A, et al. (2011) Methylated genes in breast cancer: associations with clinical and histopathological features in a familial breast cancer cohort. Cancer Biol Ther 11:853-865. doi: 15177 [pii]

47. Irianto J, Pfeifer CR, Ivanovska IL, et al. (2016) Nuclear Lamins in Cancer. Cell Mol Bioeng 9:258-267. doi: 10.1007/s12195-016-0437-8

48. Ferguson AT, Lapidus RG, Baylin SB, Davidson NE (1995) Demethylation of the estrogen receptor gene in estrogen receptor-negative breast cancer cells can reactivate estrogen receptor gene expression. Cancer Res 55:2279-2283.

49. Momparler RL, Bovenzi V (2000) DNA methylation and cancer. J Cell Physiol 183:145-54. doi: 10.1002/(SICI)1097-4652(200005)183:2<145::AIDJCP1>3.0.CO;2-V

50. Tommasi S, Karm DL, Wu X, et al. (2009) Methylation of homeobox genes is a frequent and early epigenetic event in breast cancer. Breast Cancer Res 11:R14. doi: bcr2233 [pii]10.1186/bcr2233

51. Yang L, Guan T, Gerace L (1997) Lamin-binding fragment of LAP2 inhibits increase in nuclear volume during the cell cycle and progression into $\mathrm{S}$ phase. $\mathrm{J}$ Cell Biol 139:1077-1087. 
Table 1 clinico-pathological criteria of study patients

\begin{tabular}{|l|l|}
\hline Clinico-pathological parameter & No. of patients (\%) \\
\hline $\begin{array}{l}\text { Age } \leq 50 \text { years } \\
\text { Age } \geq 50 \text { years }\end{array}$ & $\begin{array}{l}609(32.9) \\
629(67)\end{array}$ \\
\hline $\begin{array}{l}\text { Local recurrence } \\
\text { Distant metastasis }\end{array}$ & $392(41.8)$ \\
$302(32.2)$
\end{tabular}


Table 2 Correlation of Lamin A/C expression with clinico-pathological parameters

\begin{tabular}{|c|c|c|c|}
\hline & Lamin A/C & & \\
\hline Parameter & $\begin{array}{l}\text { Negative } \\
n=540(\%)\end{array}$ & $\begin{array}{l}\text { Positive } \\
n=398(\%)\end{array}$ & p-Value \\
\hline \multicolumn{4}{|l|}{ Grade } \\
\hline 1 & $60(11.2)$ & $81(20)$ & \multirow{4}{*}{$<0.001$} \\
\hline 2 & $134(25)$ & $137(34.9)$ & \\
\hline 3 & $346(64.3)$ & $176(44.8)$ & \\
\hline Total & 540 & 394 & \\
\hline \multicolumn{4}{|l|}{ LN Stage } \\
\hline 1 & $311(57.9)$ & $245(62.2)$ & \multirow{4}{*}{0.354} \\
\hline 2 & $173(32.2)$ & $118(30)$ & \\
\hline 3 & $53(10)$ & $31(7.9)$ & \\
\hline Total & 538 & 393 & \\
\hline \multicolumn{4}{|l|}{ Tumour size } \\
\hline$<1.5 \mathrm{~cm}$ & $98(18.2)$ & $100(25.4)$ & \multirow[b]{2}{*}{0.004} \\
\hline$\geq 1.5 \mathrm{~cm}$ & $440(81.8)$ & $293(74.6)$ & \\
\hline Total & 538 & 393 & \\
\hline \multicolumn{4}{|c|}{ Distant metastases } \\
\hline No & $352(65.3)$ & 278(70.7) & \\
\hline
\end{tabular}




\begin{tabular}{|c|c|c|c|}
\hline Definite & $187(34.7)$ & $115(29.3)$ & 0.027 \\
\hline Total & 539 & 393 & \\
\hline \multicolumn{4}{|c|}{ Nottingham Prognostic Index } \\
\hline Good & $107(20$ & $122(31)$ & \\
\hline Moderate & $294(54.7)$ & $209(53.3)$ & $<0.001$ \\
\hline Poor & $136(25.3)$ & $61(15.6)$ & \\
\hline Total & 537 & 392 & \\
\hline \multicolumn{4}{|l|}{ Tubules } \\
\hline 1 & $21(4)$ & 26(6.9) & \\
\hline 2 & $150(28.5)$ & $142(37.6)$ & 0.001 \\
\hline 3 & $355(67.5)$ & $210(55.6)$ & \\
\hline Total & 526 & 378 & \\
\hline \multicolumn{4}{|c|}{ Pleomorphism } \\
\hline 1 & $3(0.6)$ & $8(2.1)$ & \\
\hline 2 & $154(29.3)$ & $157(41.8)$ & $<0.001$ \\
\hline 3 & $369(70.2)$ & $211(56)$ & \\
\hline Total & 526 & 376 & \\
\hline \multicolumn{4}{|l|}{ Mitosis } \\
\hline 1 & $130(24.7)$ & $144(38)$ & \\
\hline 2 & $84(16)$ & $82(21.7)$ & $<0.001$ \\
\hline 3 & $312(59.3)$ & $152(40.2)$ & \\
\hline Total & 526 & 378 & \\
\hline \multicolumn{4}{|c|}{ Vascular Invasion } \\
\hline Negative & $337(63)$ & $279(70.8)$ & \multirow{2}{*}{0.014} \\
\hline Probable & 197(36.9) & $115(29.2)$ & \\
\hline Total & 534 & 394 & \\
\hline
\end{tabular}




\begin{tabular}{|c|c|c|}
\hline Tumour type & $\begin{array}{l}\text { Negative } \\
\text { (\%) }\end{array}$ & $\begin{array}{l}\text { Positive } \\
\text { (\%) }\end{array}$ \\
\hline Invasive Ductal/No Special Type & $367(67.6)$ & $215(54.0)$ \\
\hline Tubular Mixed & $72(13.3)$ & 79(19.8) \\
\hline Atypical Medullary & $21(3.9)$ & $5(1.3)$ \\
\hline Classical Lobular & $21(3.9)$ & $21(5.3)$ \\
\hline Lobular Mixed & 10(1.9) & $17(4.3)$ \\
\hline Mixed NST And Lobular & $15(2.8)$ & $16(4)$ \\
\hline Tubular & $11(2)$ & $13(3.3)$ \\
\hline Mixed NST And A Special Type & $6(1.1)$ & $7(1.8)$ \\
\hline Mucinous & $4(0.7)$ & $2(0.5)$ \\
\hline Typical Medullary & $1(0.2)$ & $2(0.5)$ \\
\hline Solid Lobular & $1(0.2)$ & $1(0.3)$ \\
\hline Tubulo-lobular & 0 & $2(0.5)$ \\
\hline Invasive Papillary & $2(0.4)$ & $1(0.3)$ \\
\hline Miscellaneous types & $10(1.9)$ & $16(4.0)$ \\
\hline Total & 540 & 398 \\
\hline \multicolumn{3}{|l|}{$P=0.002$} \\
\hline
\end{tabular}

Table 3 Association of lamin A/C expression in breast cancer with histological type 
Table 4 The relationship between Lamin A/C expression, hormonal receptors and other tumour markers expression

\begin{tabular}{|c|c|c|c|c|}
\hline & & \multicolumn{3}{|l|}{$\operatorname{Lamin} \mathrm{A} / \mathrm{C}$} \\
\hline Patients & & Negative (\%) & Positive (\%) & $p$ value \\
\hline \multirow[t]{3}{*}{ ER } & Negative & $175(33.3)$ & $88(22.8)$ & \\
\hline & Positive & $353(67.0)$ & $299(77.0)$ & 0.002 \\
\hline & Total & 528 & 387 & \\
\hline \multirow[t]{2}{*}{ PgR } & Negative & $246(47.2)$ & $134(35.4)$ & \\
\hline & Positive & $275(53.0)$ & $244(64.5)$ & 0.001 \\
\hline
\end{tabular}




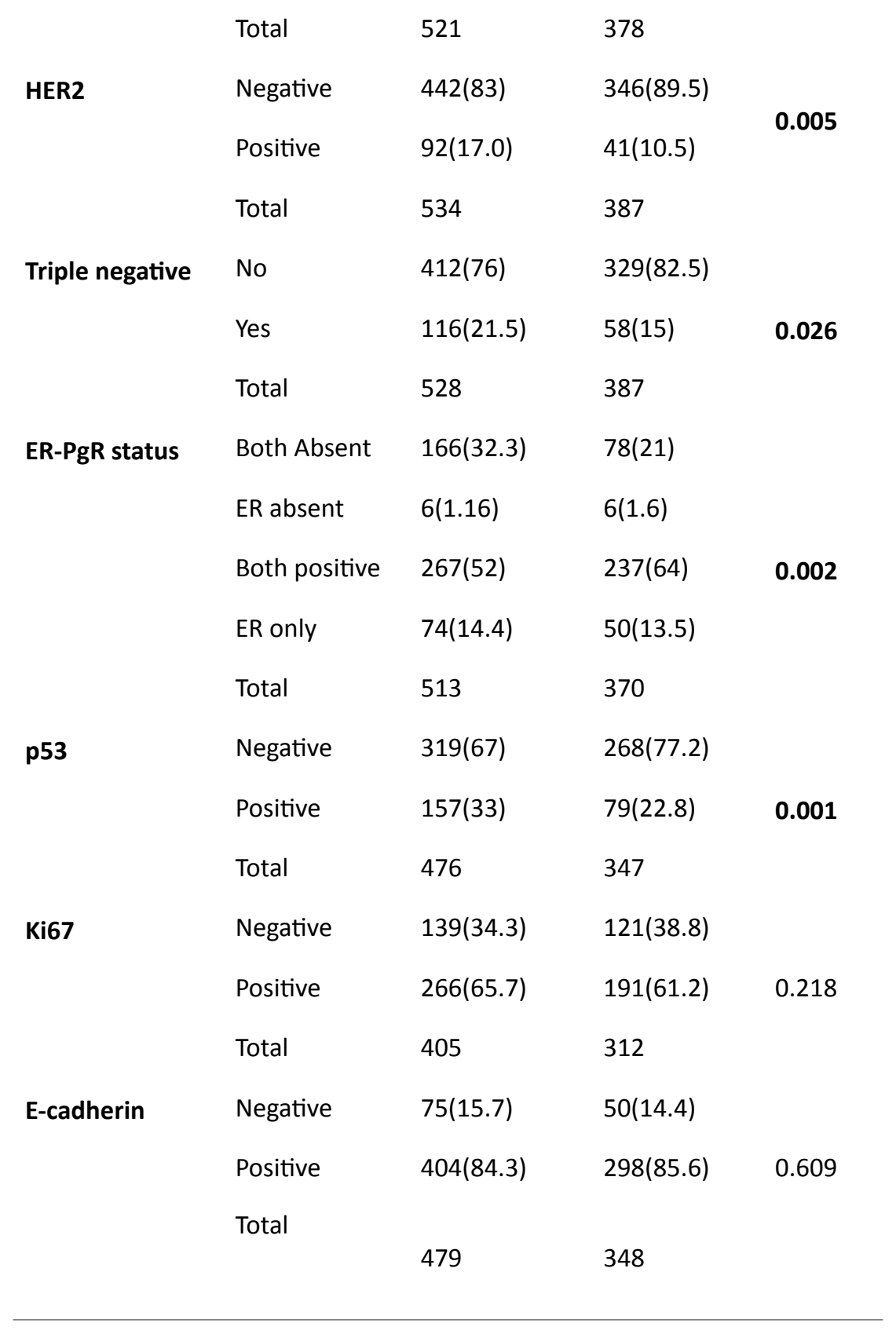

Table 5 Cox proportional hazards analysis for predictors of breast cancer specific survival (BCSS) and disease-free survival (model including lamin A/C expression) 


\begin{tabular}{|c|c|c|c|c|c|c|}
\hline \multicolumn{4}{|c|}{ Breast cancer specific survival } & \multicolumn{2}{|c|}{$\begin{array}{l}\text { Dis ease-free } \\
\text { (recurrence) }\end{array}$} & \multirow{2}{*}{$\begin{array}{r}\text { survival } \\
95 \% \mathrm{CI}\end{array}$} \\
\hline Variable & $\begin{array}{l}\text { Hazard } \\
\text { ratio }\end{array}$ & p-value & $95 \% \mathrm{CI}$ & $\begin{array}{l}\text { H a z a r d } \\
\text { ratio }\end{array}$ & p-value & \\
\hline $\begin{array}{l}\text { T u m o u r } \\
\text { size }\end{array}$ & 2.153 & $<0.001$ & $\begin{array}{l}1.408-3.2 \\
90\end{array}$ & 1.475 & 0.008 & $\begin{array}{l}1.105-1 \\
967\end{array}$ \\
\hline $\begin{array}{l}\text { Tu m o u r } \\
\text { stage }\end{array}$ & 1.750 & $<0.001$ & $\begin{array}{l}1.480-2.0 \\
68\end{array}$ & 1.651 & $<0.001$ & $\begin{array}{l}1.424-1 \\
914\end{array}$ \\
\hline $\begin{array}{l}\text { T u m o u r } \\
\text { grade }\end{array}$ & 1.965 & $<0.001$ & $\begin{array}{l}1.584-2.4 \\
37\end{array}$ & 1.271 & 0.002 & $\begin{array}{l}1.092-1 \\
479\end{array}$ \\
\hline $\operatorname{Lamin} \mathrm{A} / \mathrm{C}$ & 0.876 & 0.304 & $\begin{array}{l}0.680-1.1 \\
28\end{array}$ & 0.988 & 0.905 & $\begin{array}{l}0.803-1 \\
214\end{array}$ \\
\hline
\end{tabular}




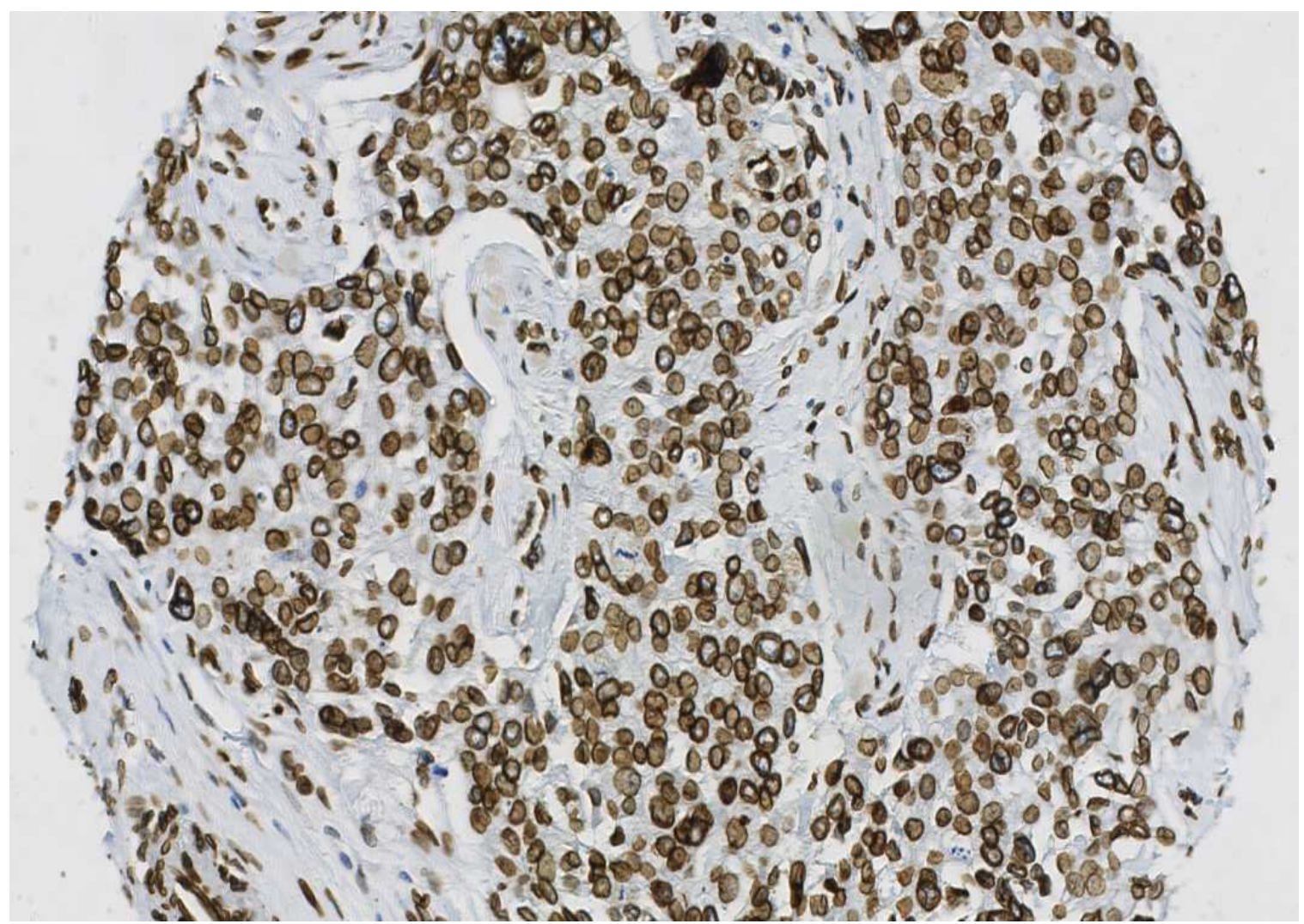

Fig. 1 
Fig. 2

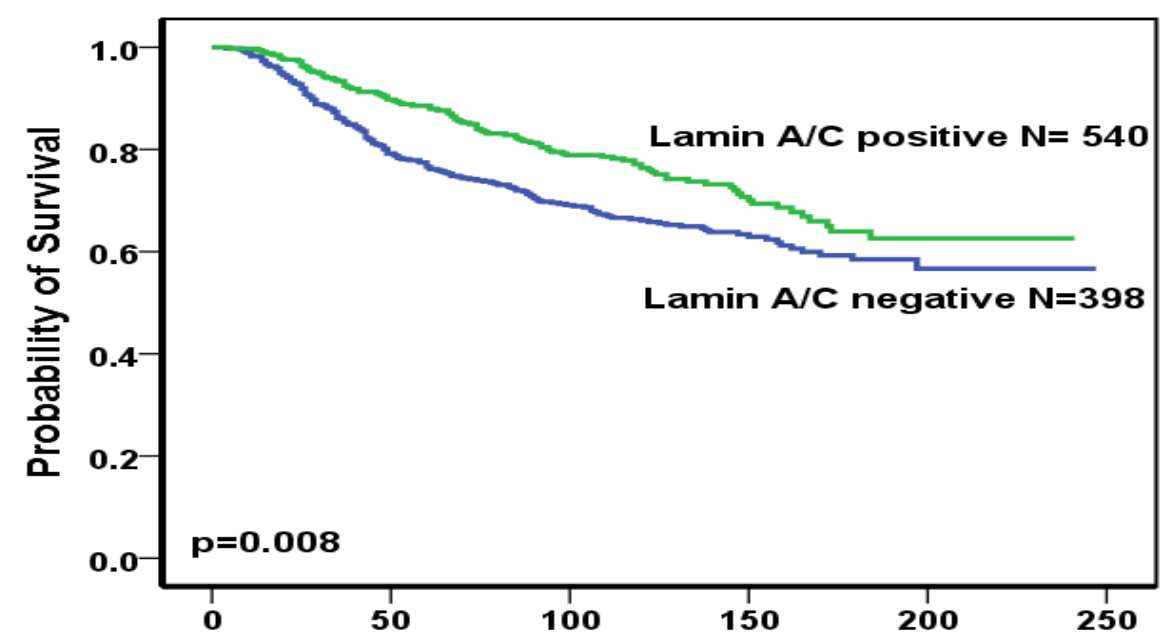

Fig. 3

Breast cancer specific survival in months

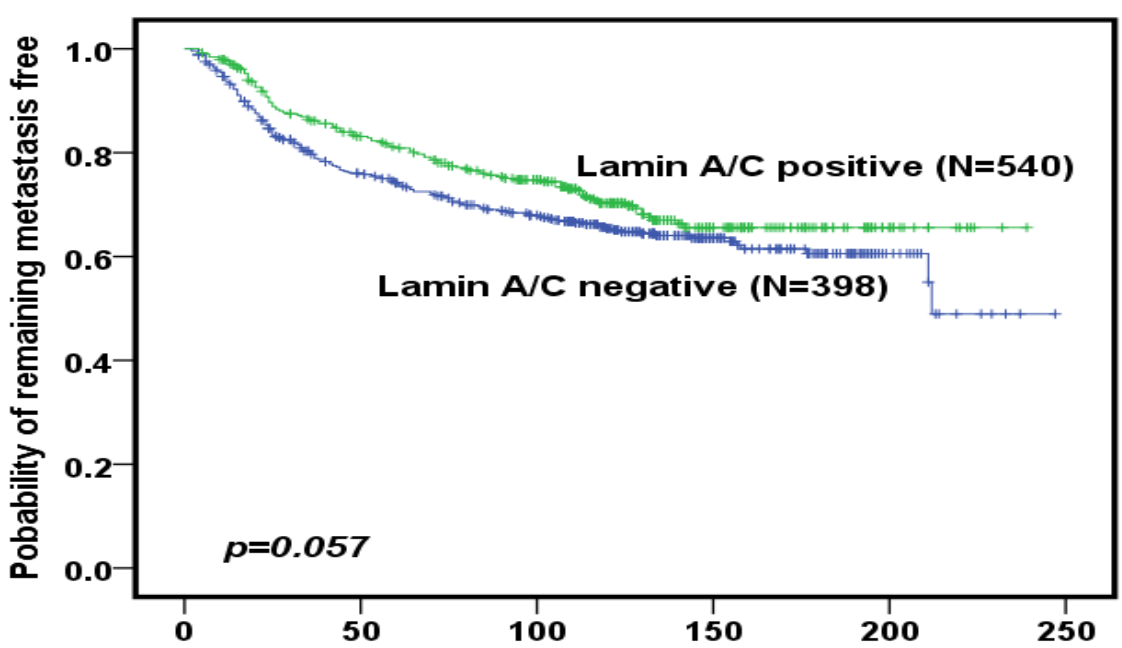

Fig. 4

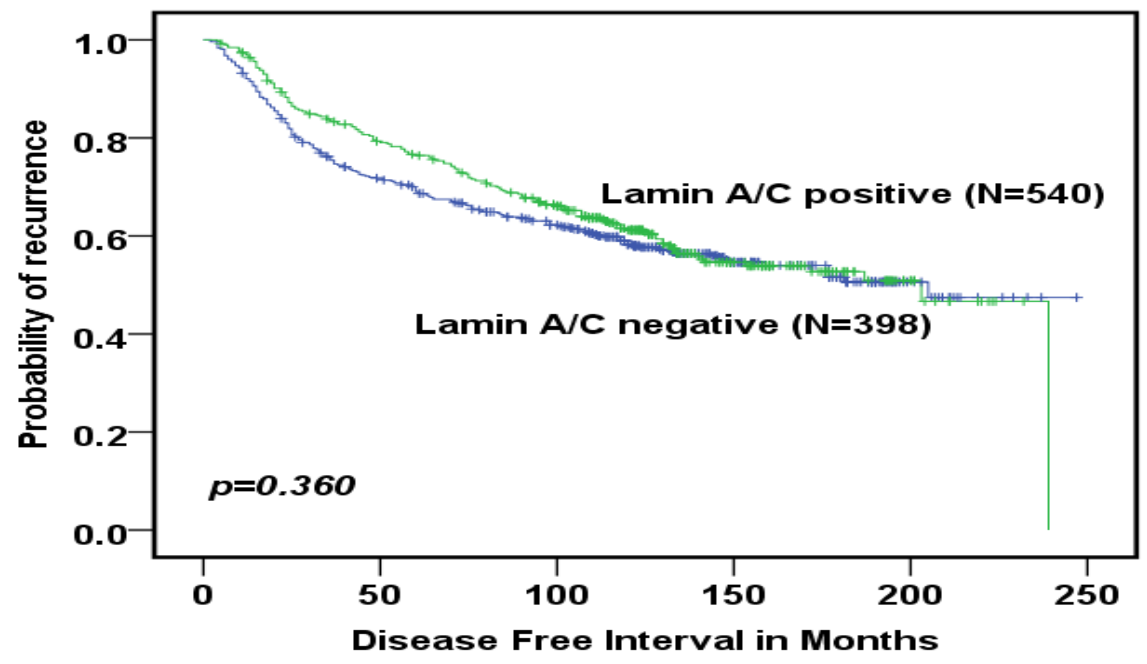




\section{Figure Legends}

Fig. 1 Photograph showing positive lamin A/C nuclear staining in breast determined using immunohistochemistry. 15x magnification

Fig. 2 Lamin A/C expression in relation to BCSS in breast tumours

Fig. 3 Lamin A/C expression in relation to DFI (metastasis) in breast tumours

Fig. 4 Lamin A/C expression in relation to DFI (Locoregional Recurrence) in breast tumours 